\title{
The Application of PFMEA for Roller Bearings Production
}

\author{
Lucie Krejci $^{1}$, Vladimira Schindlerova ${ }^{1}$, Michal Bucko ${ }^{1}$, Ivo Hlavaty ${ }^{1}$, Milos Mician ${ }^{2}$ \\ ${ }^{1}$ Faculty of Mechanical Engineering, VSB - Technical University of Ostrava. 17. listopadu 2172/15, 70800 Ostrava- \\ Poruba. Czech Republic. E-mail: lucie.krejci@vsb.cz, vladimira.schindlerova@vsb.cz, michal.bucko@vsb.cz, ivo.hla- \\ vaty@vsb.cz \\ ${ }^{2}$ Faculty of Mechanical Engineering, University of Zilina. Univerzitna 8215/1, 01026 Zilina. Slovakia. E-mail: \\ milos.mician@fstroj.uniza.sk
}

\begin{abstract}
An important trend today is the continual improvement of product quality with the objective of increased customer satisfaction, but also leading to more effective cost reduction management. Effective quality management in a company also enables increasing production productivity thanks to the increasing amount of top-quality products made and the consequent minimalization of repairs of non-conforming workpieces. This contribution deals with one of the important tools for ensuring quality in the production process using the FMEA (Failure Mode and Effect Analysis) method used in the production of roller bearings for the automobile industry.
\end{abstract}

Keywords: PFMEA, The analyses of defects and their consequences, Bearings, Automobile industry, Quality

\section{Introduction}

Production companies are continuously forced to improve their position on the market, and as a result of it customers are continuously increasing their demands for top-quality production. What is required is the highest quality product for the lowest possible price. The optimalized management of quality in a company enables an increase in productivity and a reduction of the number of non-conforming workpieces. Introducing FMEA into a production company ensures an up-to-date overview on the occurrence of already recorded and newly discovered defects. A timely reaction, the setting up of preventative measures and inspections (detection) ensures a solution to the cause of defect formation and a reduction of its repeated occurrence. FMEA is denoted as a document, which is subject to continuous examination and is up-dated on the basis of experience and daily work information. [1,2]

FMEA is therefore a necessary part of risk management and helps in the continuous improvement of quality in process areas, and is also one of the main methods, which are part of the product process and development. It is possible to characterize it as the continuous analysis of a product in every phase of the production process, from inspecting the quality of the materials used, which are in the various phases of production, to product management in storage. [3, 4]

The FMEA method was established in the year 1949 in the USA as a military regulation for evaluating reliability and stating the impact of system and equipment breakdown. In the year 1963 NASA developed the FMEA method for the projects Apollo, Viking and Voyager, and consequently in the year 1965 aeronautics and astronautics took over this method from NASA (Fig. 1). In the year 1974 the FMEA method was also used by the American navy (MIL-STD-1629). It was first used in the automobile industry in the year 1977 for preventative quality assurance, and especially further developed for cars in the automobile industry (VDA). [5, 9]

In Germany in 1980 in DIN 25448 there was stated the method of analysing breakdown results under the subtitle FMEA. In the 1990s FMEA also expanded into the medical industry and IT and at the end of the decade a working group was established, founded by the German Quality Association, with the objective of applying FMEA to other non-technical branches. [3, 6]

An unit interested in assessing the FMEA method are the technological areas of production in engineering, to which welding, welding-on and soldering technology are assigned and used in engineering areas. An important category for assessing FMEA are the heterogeneous welded joints of nuclear and conventional power plants and the heteorgeneous spikes used in equipment in the construction, extraction, mining and agricultural industries. $[7,10,14]$

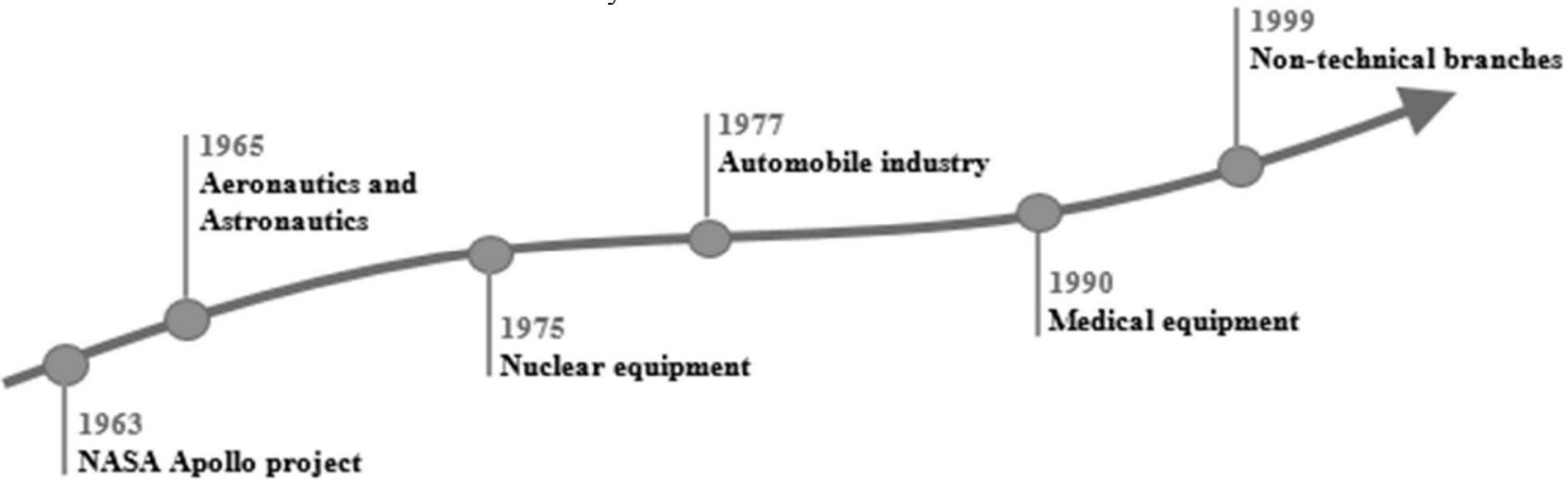

Fig. 1 The development of FMEA methods [3] 


\section{FMEA application}

It is possible to divide the FMEA method into two phases. The first phase is represented by the design and development of a new product and the second phase is consequently the production process itself. The FMEA design of a product, indicated as DFMEA (Design Failure Mode and Effect Analysis), is an analysis of possible methods and the consequences of breakdown during product design and the FMEA process, while PFMEA (Process Failure Mode and Effect Analysis) is indicated as an analysis supporting the development of the production process to moderate the possible occurrence of breakdowns (Fig. 2). One of the most important elements of successfully introducing FMEA is its timeliness. Implementing a FMEA product or process in advance allows you to apply changes more easily and more cheaply due to the timely discovery of possible defects. In using the FMEA method it is necessary to carry out the following steps according to the following guidelines:

- to choose an object for analyzing a process or its parts;

- to describe the present state of a manufactured product;

- to identify all defects and to define their causes;

- to determine the significance of the defects, the risks of the occurrence and detection. [8]

The reason for applying PFMEA is the continuous improvement of products, processes, reliability and a reduction of the number of claims, by which the number of customers and their satisfaction will be increased. [11]

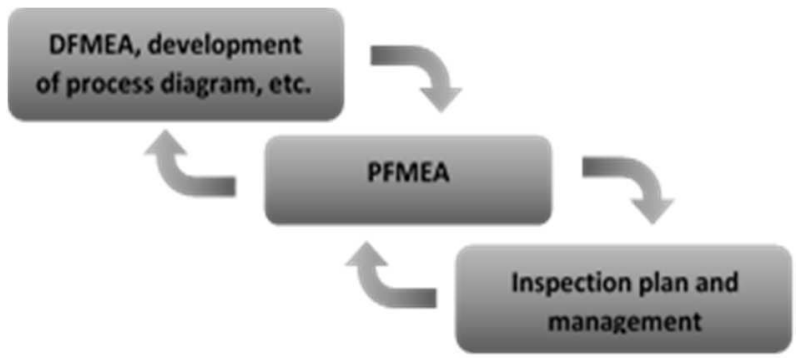

Fig. 2 The relation between DFMEA and PFMEA [9]

In applying FMEA it is necessary to map out the production process, to analyze the possible defects, to define the causes and to set acceptable measures for reducing risk. [13] Assessing risk during the procedure of the FMEA process is evaluated using three characteristics the severity, occurrence and detection. Each of these criteria is evaluated according to tables with a scale from ,110 ", whose value 10 is undesirable and represents a nonfulfillment of the safety requirements and regulations. Value 1 is desirable and represents a fulfillment of the safety requirements and regulations.

\section{Among the evaluation parameters there is:}

- Severity (S) is the value, which is connected with the most serious consequences in the case of a defect method.
- Occurrence $(\mathrm{O})$ states the probability of the occurrence of a defect in a process and takes into consideration given measures to limit it.

- Detection (D) is a relative assessment, which is connected with the instrument used for detection management with the objective of achieving a low number, and it is necessary to improve the planned detection tool.

The product of these three criteria for each defect is a RPN risk number, which is a risk indicator and states the priority of measures taken. [3, 4]

In processing FMEA it is necessary to deal with each product part or assembly. It is also necessary to devote great attention to the safety connected to components or processes. Especially in practice the procedures are valid according to the method of American car producers (QS9000: FMEA) or according to the methods of the German Automobile Association (VDA), whose principles are similar. The use of FMEA is recommended by norm ISO 9000:2000 and is continuously being more often required by customers, who then verify that the manufacturer has assessesed and evaluated all risks as to process or product failure and that the product is therefore at the required quality. PFMEA is focused moreover on the effects and methods of process failure during production. [12]

The objective of FMEA is to prevent defects in time and to introduce measures to limit them. FMEA as a preemergence defect method is already being used at a very early stage in the product production process.

Organizations using FMEA have for example as an objective:

- to increase functional safety and the reliability of products and processes,

- to minimize the costs of production and assembly,

- to meet the required deadlines,

- to orient themselves on customer requirements,

- to create a database at companies, recording safety and measure procedures in undesirable situations, etc. $[6,15]$

\section{Case study - defect analysis in the process of roller bearing production}

Defect analysis for roller bearing production represents the basis for establishing PFMEA at a company. The PFMEA document is a document, which contains all kinds of company know-how and that is why it is not available to the public. When visiting a production plant a customer can look into PFMEA for his own components (Fig. 3). [1]

On the basis of this it was necessary to firstly create a FMEA team, made up of the representatives of the individual departments of a company (quality representives, process engineering, logistics and production). The task of the FMEA team was to gather all data, dealing with the 
occurrence of undesired defects in the production of roller bearings for individual production processes in a given year. It was consequently necessary to work these materials out in the form of the distinct kinds and numbers of the individual defects.

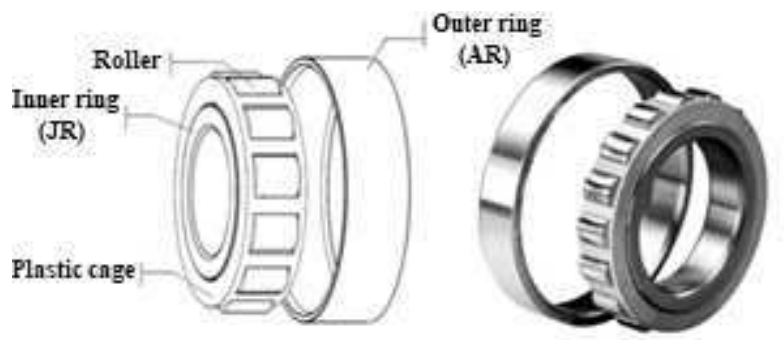

Fig. 3 Roller bearing components [1]

Materials which were available for defect occurrence analysis:

- DFMEA,
- production drawings,

- shift progress reports (a database for processing defect occurrence for one calendar year and it contains information concerning the various problems recorded in production),

- 4D reports on dealing with internal problems (4 Discipline report - a shortened 8D report version, used for dealing with internal claims),

- inspection plans,

- customer claims (the greatest number of claims for a calendar year, for example interior diameter (ID) outside the tolerance and operations left out during production (Graph 1). Furthermore, the occurrence of missing markings, part replacement and uncut inner diameters).

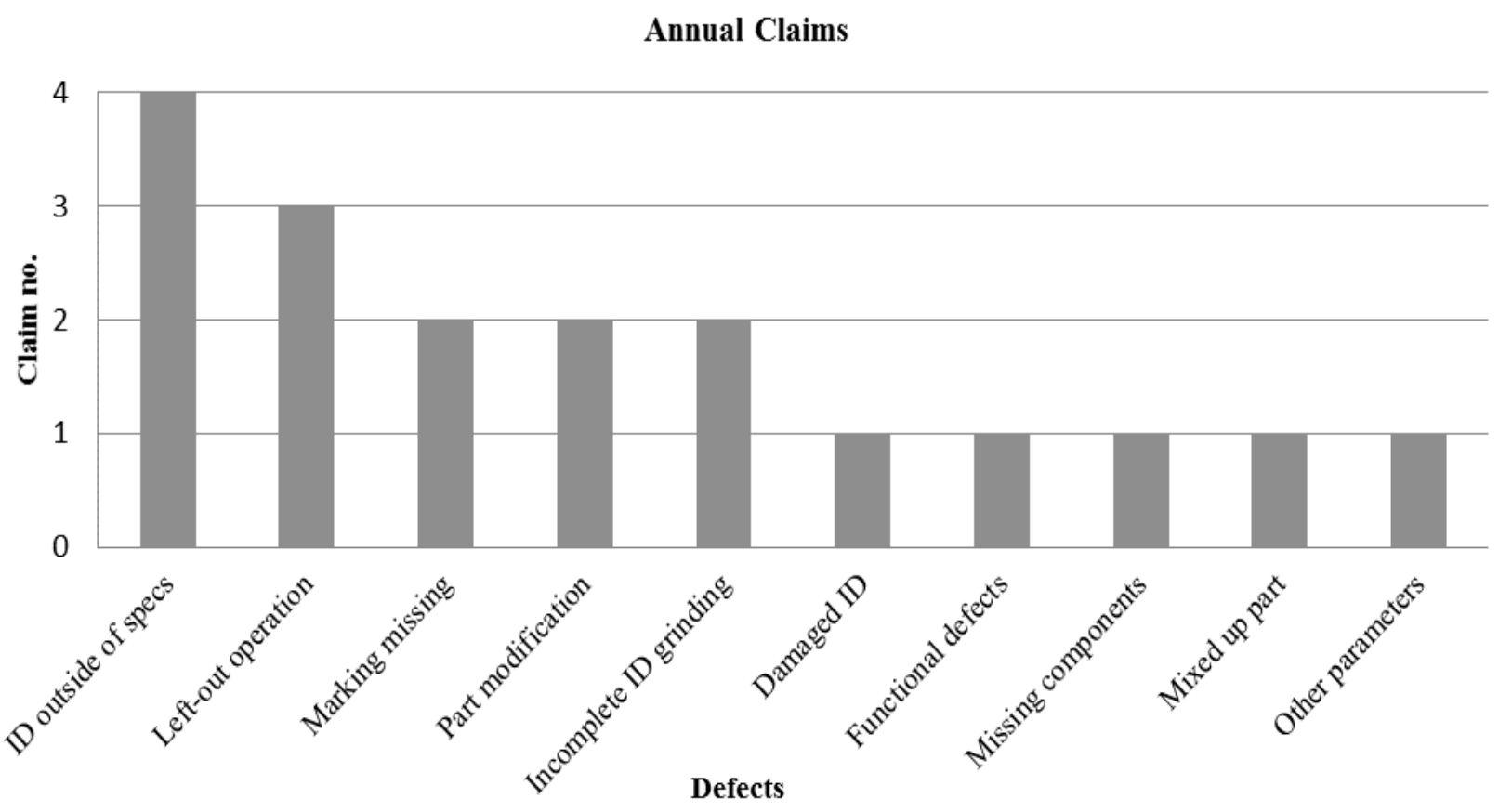

Graph 1 A summary of internal claims [1]

The main idea of the paper is to map the value flow and disadvantages. The analysis covers the current state of individual processes within the production line. After defining the existing deficiencies, a rationalization plan was created in which a combination of lean manufacturing elements was used. The proposed solutions can be used to establish lean manufacturing principles across the production line throughout the plant. If the proposed solution cannot be put into practice, it can be used as a plan for other types of improvements. $[6,9,16]$

\subsection{Evaluating the defect analysis}

On the basis of processing the input materials there were evaluated defects occuring during one calendar year in the production of the individual components of roller bearings (CRB). The defect analysis was applied in the plants of the turning, hardening and grinding machines and the components were marked with:
- AR (external ring),

- JR (internal ring),

- RA (separate ring),

- VT (valve rocker roller).

The procedure for evaluating the defect analysis (Fig. 4) was carried out by processing all supplied materials into a form from which it was consequently possible to put together the resultant analysis. With the general summary of the occurrence of defects a visual overview of them was also created. Information was obtained as a result of this analysis, which was consequently used for creating the FMEA process.

On the basis of the analysis of available materials there was discovered the complete occurence of individual kinds of defects for the evaluated components occuring in a product at specific plants. 


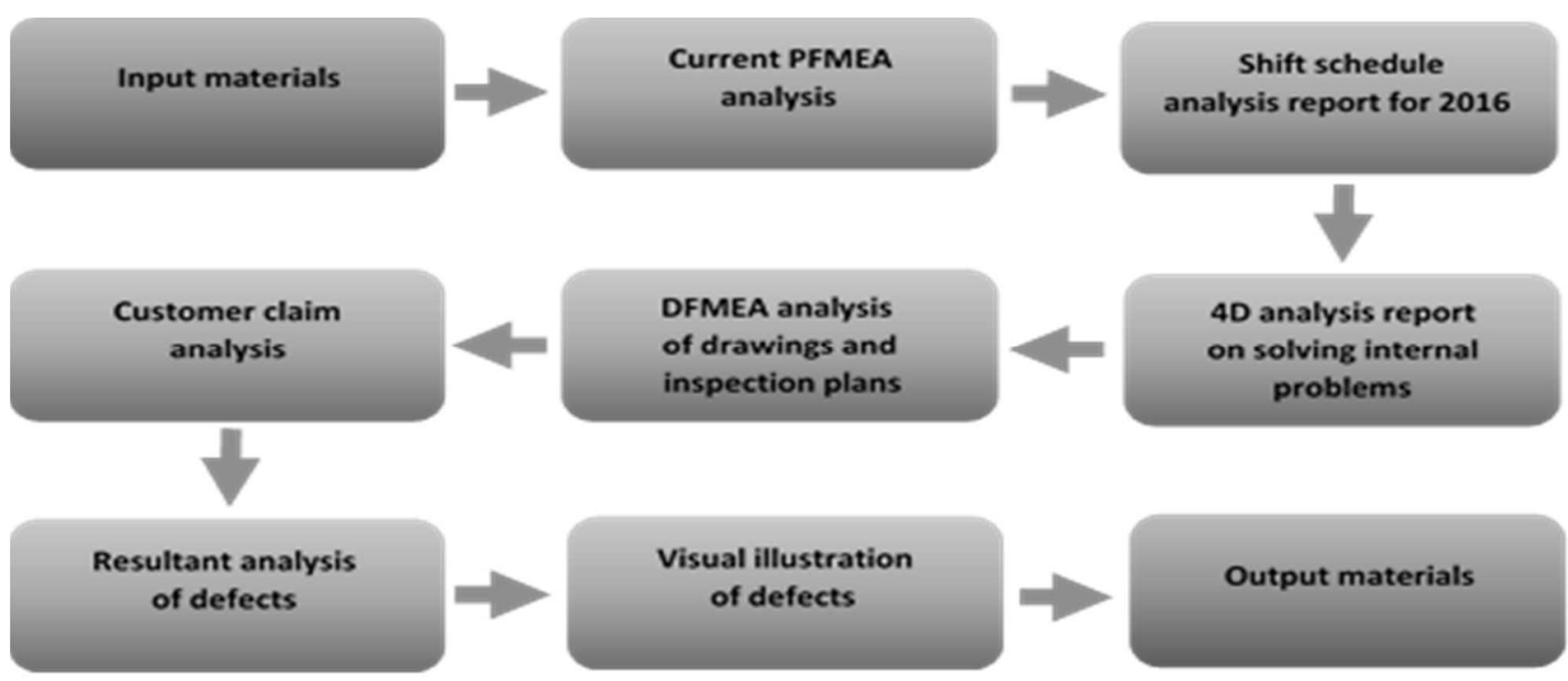

Fig. 4 The procedure for assessing the defect analysis [1]

As an overview there was created a resultant table of analysis, which is made up of columns under the names: material (AR, JR, RA, VT), order number, problem origin (turning plant, hardening plant, grinding plant, storage), the machine, defect, defect description, immediate measure, date, etc. The frequency of defect occurrence was worked out in the form of a graph (Graph 2).

From Graph 2 it is evident that According to the resultant analysis the greatest number of defects was caused by:

- a bad inner dimension (ID) $-10 \%$,

- deformation $-8 \%$,

- a bad outer dimension (OD) - $7 \%$,

- allowances $-7 \%$,

- visual defects $-7 \%$,

- missing material $-7 \%$.

\section{Kinds and the frequency of defect occurence in production}

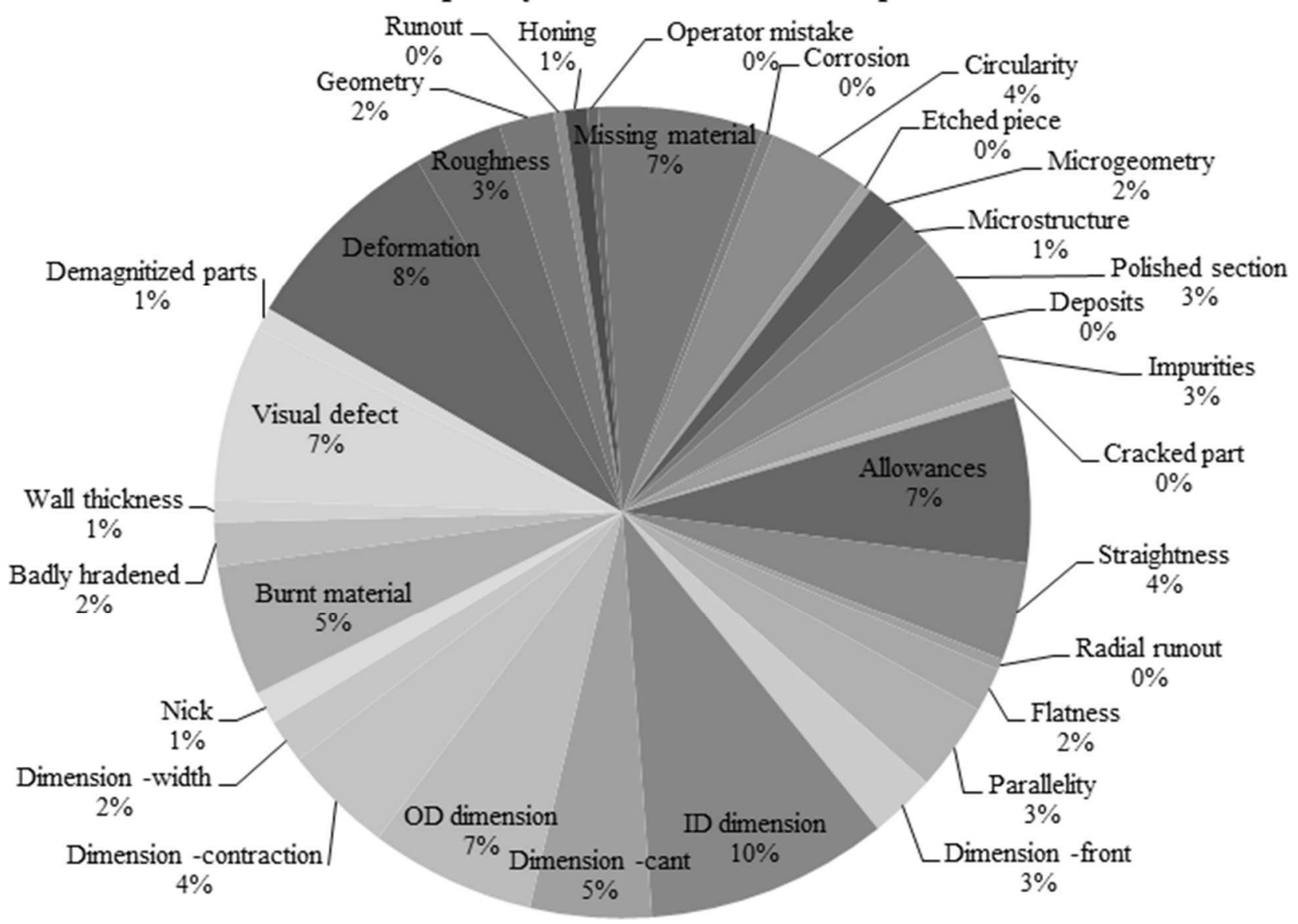

Graph 2 The frequency of defect occurrence in production [1] 


\subsection{Vizual illustration of defects}

For easier identification there were created figures and descriptions of the basic visual defects occuring on the individual components. Defects, which occurred during the analysis, were for example burnt materials or cracks. Unacceptable pieces of burnt material including cracks and thermally damaged surfaces caused by grinding, are shown in the figure (Fig. 5). Cracks are unacceptable defects and can cause ring cracking.

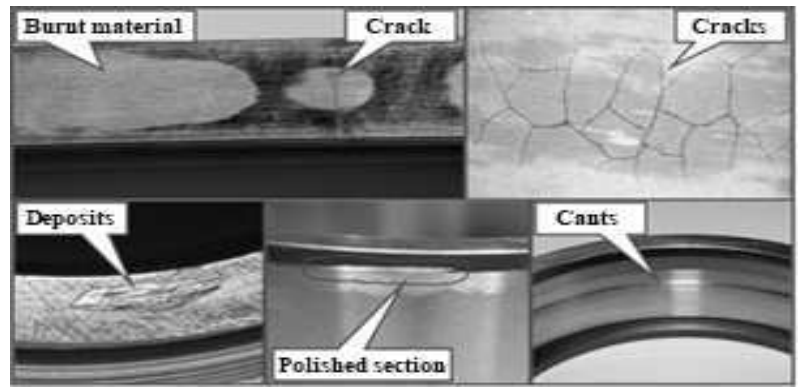

Fig. 5 A visual illustration of defect occurence [1]

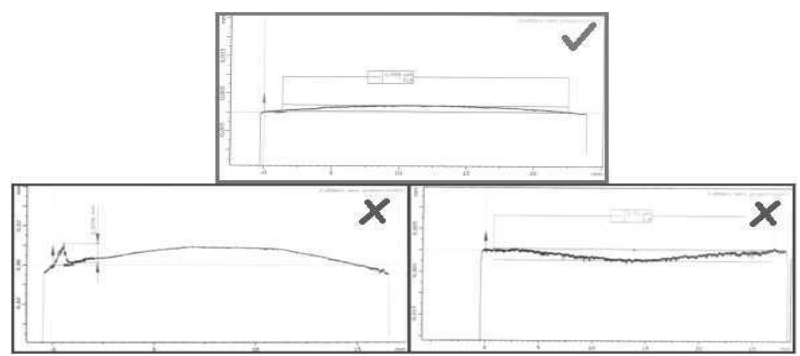

Fig. 6 Straightness shape [1]

One of the defects that occurred was an unacceptable shape of straightness and the shape of the circularity. The straightness shape must be flat or slightly convex along the entire ground surface, or according to a drawing. The shape of circularity has to be smooth and circular, and must not be in the shape of a star or multi-edged. The unacceptale shape of straightness and circularity are illustrated in the figures (Fig. 6 and Fig. 7).

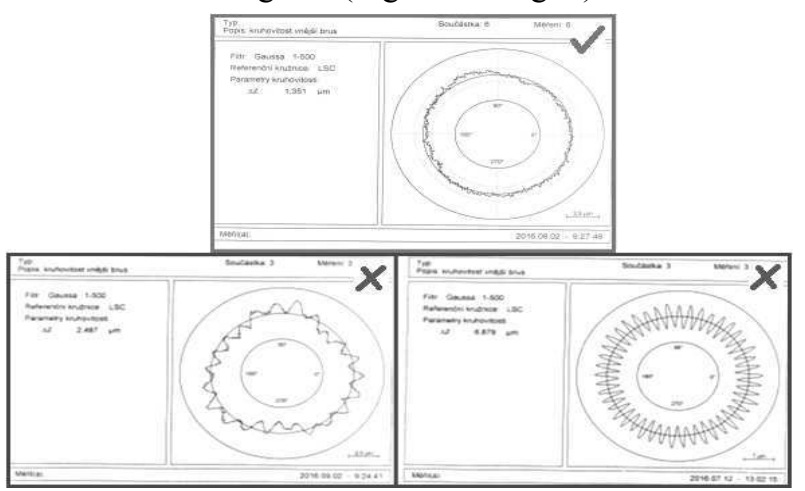

Fig. 7 Circularity shape [1]

\section{The structure of PFMEA and the regulations for use}

Another procedure, necessary for gathering PFMEA, was to identify the defect results, that is the impact on the final application, or following operations, and to evaluate the occurrence of defects using the three characteristics (significance, occurrence, detection). The table contains the frequency of measurements for stating the detection (Tab. 1).

After evaluating the individual occurrence of defects the determination of the priority indicators of risk RPN followed, that is used to determine the priority of measures. The risk number of the individual possible defects formed by a specific cause is calculated as a summary of the values of severity, occurrence and detection (Tab. 2).

Tab. 1 Measurement frequency for stating the detection [1]

\begin{tabular}{|c|c|c|c|}
\hline Operation & Inspection code & Measurement frequency & Detection \\
\hline Outer diameter cutting at the finish & Visual inspection & 3 pieces -5 min. & 8 \\
\hline \multirow{2}{*}{ Orbit grinding } & Visual inspection & 4 pieces -20 min. & 8 \\
\cline { 2 - 4 } & Radical setting & 4 pieces -20 min. & 9 \\
\hline Orbit honing & Visual inspection & 4 pieces -20 min. & 8 \\
\hline Visual inspections & Visual inspection & $100 \%$ of the orders & 8 \\
\hline
\end{tabular}

Tab. 2 The basic database for creating PFMEA [1]

\begin{tabular}{|c|c|c|c|c|c|c|c|}
\hline $\begin{array}{l}\text { Part } \\
\text { type }\end{array}$ & Process & Defect & Result & $\begin{array}{l}\text { Severity } \\
\text { (S) }\end{array}$ & $\begin{array}{l}\text { Occurrence } \\
(\mathrm{O})\end{array}$ & $\begin{array}{l}\text { Detection } \\
\text { (D) }\end{array}$ & RPN \\
\hline AR & $\begin{array}{l}\text { Grinding } \\
\text { plant }\end{array}$ & $\begin{array}{l}\text { Burnt orbit of outer } \\
\text { ring }\end{array}$ & $\begin{array}{l}\text { Bearing life reduction - } \\
\text { bearing failure }\end{array}$ & 8 & 4 & 8 & 256 \\
\hline AR & $\begin{array}{l}\text { Grinding } \\
\text { plant }\end{array}$ & $\begin{array}{l}\text { Burnt outer diameter } \\
\text { of outer ring }\end{array}$ & $\begin{array}{l}\text { Bearing life reduction - } \\
\text { ring cracking }\end{array}$ & 8 & 4 & 8 & 256 \\
\hline AR & $\begin{array}{l}\text { Grinding } \\
\text { plant }\end{array}$ & $\begin{array}{l}\text { Visual defect of outer } \\
\text { ring }\end{array}$ & $\begin{array}{l}\text { Bearing life reduction - } \\
\text { bearing failure }\end{array}$ & 7 & 6 & 8 & 336 \\
\hline $\begin{array}{l}\text { Part } \\
\text { type }\end{array}$ & Process & Defect & Result & $\begin{array}{l}\text { Severity } \\
(\mathrm{S})\end{array}$ & $\begin{array}{c}\text { Occurrence } \\
(\mathrm{O})\end{array}$ & $\begin{array}{c}\text { Detection } \\
\text { (D) }\end{array}$ & RPN \\
\hline JR & $\begin{array}{l}\text { Grinding } \\
\text { plant }\end{array}$ & $\begin{array}{l}\text { Big radical runout of } \\
\text { inner ring }\end{array}$ & $\begin{array}{l}\text { Big total bearing runout - } \\
\text { Bearing life reduction }\end{array}$ & 7 & 5 & 9 & 315 \\
\hline JR & $\begin{array}{l}\text { Grinding } \\
\text { plant }\end{array}$ & $\begin{array}{l}\text { Visual defect of inner } \\
\text { ring }\end{array}$ & $\begin{array}{l}\text { Bearing life reduction - } \\
\text { bearing failure }\end{array}$ & 7 & 6 & 8 & 336 \\
\hline JR & $\begin{array}{l}\text { Grinding } \\
\text { plant }\end{array}$ & Corrosion & $\begin{array}{l}\text { Bearing life reduction - } \\
\text { bearing failure }\end{array}$ & 7 & 6 & 8 & 336 \\
\hline
\end{tabular}


For the summarized processing of the PFMEA database a PFMEA form was designed, which contains basic information dealing with creation, process responsibility, the project team, processed data, the examination date, etc. The form itself contains the individual production areas, process steps, possible methods, results, defect causes and their assessment in regards to severity, occurrence and detection. By multiplying these parameters a RPN risk number is obtained. For defects with a high RPN number or severity there is consequently determined measures to minimalize them. The risk number (RPN) in each failure regime is calculated so that breakdowns with high risks are identified. [4]

Defects with a high RPN number in the PFMEA database are recorded in the PFMEA form (Tab. 3), including their assessment and the consequent measures.

Tab. 3 The PFMEA form [1]

\begin{tabular}{|c|c|c|c|c|c|c|c|c|c|c|c|c|c|c|c|c|}
\hline \multirow[b]{2}{*}{ Plant } & \multirow[b]{2}{*}{$\begin{array}{l}\text { Process } \\
\text { step } / \\
\text { Function }\end{array}$} & \multirow[b]{2}{*}{$\begin{array}{l}\text { Possible } \\
\text { defect } \\
\text { method }\end{array}$} & \multirow[b]{2}{*}{$\begin{array}{c}\text { Possible } \\
\text { defect } \\
\text { conseque } \\
\text { nces }\end{array}$} & \multirow[b]{2}{*}{ 胥 } & \multirow[b]{2}{*}{$\begin{array}{c}\text { Possible defect } \\
\text { causes }\end{array}$} & \multicolumn{4}{|c|}{ Construction process } & \multirow[b]{2}{*}{$\frac{z}{a}$} & \multirow[b]{2}{*}{$\begin{array}{c}\text { Recommended } \\
\text { measure }\end{array}$} & \multirow[b]{2}{*}{$\begin{array}{c}\text { Response } \\
\text { and } \\
\begin{array}{c}\text { Completion } \\
\text { Date }\end{array}\end{array}$} & \multicolumn{4}{|c|}{ Results of Measure } \\
\hline & & & & & & $\begin{array}{c}\text { Prevention } \\
\text { management tool }\end{array}$ & 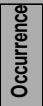 & $\begin{array}{c}\text { Detection } \\
\text { mangement tool }\end{array}$ & 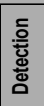 & & & & 承 & 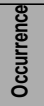 & 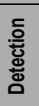 & $\frac{z}{\alpha}$ \\
\hline \multirow[t]{5}{*}{$\begin{array}{l}\text { Grinding } \\
\text { Plant }\end{array}$} & \multirow{5}{*}{\begin{tabular}{|l|} 
AR - \\
grinding \\
OD
\end{tabular}} & \multirow{2}{*}{\begin{tabular}{|l} 
Visual \\
defects \\
(grooves, \\
burrs, \\
shanks)
\end{tabular}} & \multirow{2}{*}{\begin{tabular}{|l|}
$\begin{array}{l}\text { Bearing } \\
\text { life } \\
\text { reduction }\end{array}$ \\
Bearing \\
failure
\end{tabular}} & \multirow{2}{*}{7} & $\begin{array}{l}\text { Badly entered } \\
\text { grinding } \\
\text { parameters }\end{array}$ & $\begin{array}{l}\text { Adjustment plan } \\
\text { and set-up guide }\end{array}$ & 6 & $\begin{array}{l}\text { Inspection } 3 \\
\text { pieces per } 5 \mathrm{~min}\end{array}$ & 8 & 336 & \begin{tabular}{|l} 
Check \\
machine \\
condition and \\
training
\end{tabular} & Technician & 7 & 4 & 8 & 224 \\
\hline & & & & & \begin{tabular}{|l|} 
Ignorance of \\
visual standard
\end{tabular} & $\begin{array}{l}\text { Visual standard } \\
\text { training }\end{array}$ & 4 & $\begin{array}{l}\text { Inspection } 3 \\
\text { pieces per } 5 \mathrm{~min}\end{array}$ & 8 & 224 & \begin{tabular}{|l} 
Operator \\
training on \\
visual \\
standard of \\
lines
\end{tabular} & Foreman & 7 & 3 & 8 & 168 \\
\hline & & $\begin{array}{l}\text { Burnt } \\
\text { orbit }\end{array}$ & \begin{tabular}{|l|} 
Bearing \\
life \\
reduction
\end{tabular} & 8 & $\begin{array}{l}\text { Badly entered } \\
\text { grinding } \\
\text { parameters } \\
\text { (speed) }\end{array}$ & $\begin{array}{l}\text { Adjustment plan } \\
\text { and set-up guide }\end{array}$ & 4 & $\begin{array}{l}\text { Verification by } \\
\text { etching at } \\
\text { release + } \\
\text { continuous } \\
\text { check during } \\
\text { shifts } \\
\end{array}$ & 8 & 256 & $\begin{array}{l}\text { Check } \\
\text { machine } \\
\text { condition and } \\
\text { training }\end{array}$ & Technician & 8 & 3 & 8 & 192 \\
\hline & & \multirow{2}{*}{$\begin{array}{l}\text { Burnt } \\
\text { outer } \\
\text { diameter }\end{array}$} & \multirow{2}{*}{\begin{tabular}{|l|}
$\begin{array}{l}\text { Bearing } \\
\text { life } \\
\text { reduction }\end{array}$ \\
Bearing \\
crack
\end{tabular}} & \multirow[t]{2}{*}{8} & $\begin{array}{l}\text { Badly entered } \\
\text { grinding } \\
\text { paramters } \\
\text { (speed) }\end{array}$ & $\begin{array}{l}\text { Adjustment plan } \\
\text { and set-up guide }\end{array}$ & 4 & $\begin{array}{l}\text { Verification by } \\
\text { etching at } \\
\text { release + } \\
\text { continuous } \\
\text { check during } \\
\text { shifts }\end{array}$ & 8 & 256 & $\begin{array}{l}\text { Check } \\
\text { machine } \\
\text { condition and } \\
\text { training }\end{array}$ & Technician & 8 & 3 & 8 & 192 \\
\hline & & & & & \begin{tabular}{|l|} 
Ignorance of \\
visual standard
\end{tabular} & $\begin{array}{l}\text { Visual standard } \\
\text { training }\end{array}$ & 4 & $\begin{array}{l}\text { Inspection } 3 \\
\text { pieces per } 5 \text { min }\end{array}$ & 8 & 224 & $\begin{array}{l}\text { Operator } \\
\text { training on } \\
\text { visual } \\
\text { standard of } \\
\text { lines }\end{array}$ & Foreman & 7 & 3 & 8 & 168 \\
\hline \multirow[t]{5}{*}{$\begin{array}{l}\text { Grinding } \\
\text { plant }\end{array}$} & \multirow[t]{5}{*}{\begin{tabular}{|l|} 
JR - \\
grinding \\
ID
\end{tabular}} & \multirow{2}{*}{$\begin{array}{l}\text { Corrosio } \\
\text { n }\end{array}$} & \multirow[t]{2}{*}{$\begin{array}{l}\text { Bearing } \\
\text { life } \\
\text { reduction }\end{array}$} & \multirow{2}{*}{7} & $\begin{array}{l}\text { Preservation } \\
\text { procedure } \\
\text { failure }\end{array}$ & $\begin{array}{l}\text { Preservation } \\
\text { instructions }\end{array}$ & 6 & Training & 8 & 336 & \begin{tabular}{|l} 
Operator \\
training on \\
visual \\
standard of \\
lines \\
\end{tabular} & Foreman & 7 & 4 & 8 & 224 \\
\hline & & & & & \begin{tabular}{|l|} 
Ignorance of \\
visual standard
\end{tabular} & $\begin{array}{l}\text { Visual standard } \\
\text { training }\end{array}$ & 4 & $\begin{array}{l}\text { Inspection } 4 \\
\text { pieces per } 20 \\
\text { min }\end{array}$ & 8 & 224 & \begin{tabular}{|l} 
Operator \\
training on \\
visual \\
standard of \\
lines \\
\end{tabular} & Foreman & 7 & 3 & 8 & 168 \\
\hline & & $\begin{array}{l}\text { Large } \\
\text { radial } \\
\text { runout }\end{array}$ & $\begin{array}{l}\text { Large } \\
\text { total } \\
\text { bearing } \\
\text { runout }\end{array}$ & & \begin{tabular}{|l|} 
Poorly ground \\
face - frontal \\
non- \\
perpendicularit \\
y OD/ID \\
\end{tabular} & \begin{tabular}{|l|} 
Radial runout \\
measurement \\
during alignment
\end{tabular} & 5 & \begin{tabular}{|l}
1 piece \\
measurement \\
during alignment
\end{tabular} & 6 & 210 & $\begin{array}{l}\text { Face operation } \\
\text { training }\end{array}$ & Technician & 7 & 4 & 6 & 168 \\
\hline & & \multirow{2}{*}{$\begin{array}{l}\text { Visual } \\
\text { defects } \\
\text { (grooves, } \\
\text { burrs, } \\
\text { shanks) }\end{array}$} & \multirow{2}{*}{\begin{tabular}{|l|}
$\begin{array}{l}\text { Bearing } \\
\text { life } \\
\text { reduction }\end{array}$ \\
Bearing \\
failure
\end{tabular}} & \multirow{2}{*}{7} & $\begin{array}{l}\text { Badly entered } \\
\text { grinding } \\
\text { parameters }\end{array}$ & \begin{tabular}{|} 
Adjustment plan \\
and set-up guide
\end{tabular} & 6 & $\begin{array}{l}\text { Inspection } 3 \\
\text { pieces per } 5 \text { min }\end{array}$ & 8 & 336 & \begin{tabular}{|l|} 
Check \\
machine \\
condition and \\
setter training
\end{tabular} & Technician & 7 & 4 & 8 & 224 \\
\hline & & & & & \begin{tabular}{|l|} 
Ignorance of \\
visual standard
\end{tabular} & $\begin{array}{l}\text { Visual standard } \\
\text { training }\end{array}$ & 4 & $\begin{array}{l}\text { Inspection } 3 \\
\text { pieces per } 5 \mathrm{~min}\end{array}$ & 8 & 224 & $\begin{array}{l}\text { Operator } \\
\text { training on } \\
\text { visual } \\
\text { standard of } \\
\text { lines }\end{array}$ & Foreman & 7 & 3 & 8 & 168 \\
\hline
\end{tabular}

For correctly managing PFMEA these rules were defined:

- During a new discovery on the part of the customer (claim, notification, initiative), there will always be carried out an examination of the internal processes also in connection to new projects. In other cases it is determined to be at least $1 \mathrm{x}$ a year.

- In the case of determination a measure has to be followed up and its effectivity has to be evaluated and after the effect is confirmed a given defect can reach the RPN for reevaluation, preventation improvement (leading to an occurrence reduction) or increased inspection (an improvement in the detection area).

- $\quad$ The FMEA team firstly always has to deal with the highest RPN and defects with the highest number of severity (S), occurrence $(\mathrm{O})$ and detection (D).

- Special critical character significance is evaluated at least by a value of 8 .

\section{Conclusion}

The PFMEA method has been used for the production of bearings in the automobile industry. In the first phase of introducing the process FMEA method it was necessary to map out in detail all steps in the production 
process. For production defect analysis there was made available internal materials with the recordings of their individual defects in the production process during one calendar year. These materials were assessed, modified with the new findings and recorded in the summarized defect database. after the database was created the PFMEA form was designed into which was recorded all methods, causes and defect measures at the individual plants, which was consequently evaluated using criteria for determining the risk numbers. After creating the PFMEA it was consequently possible to firstly measure defects with a higher RPN number. In regards to the fact that PFMEA is indicated as a „live“ document, which must be continuously renewed with new findings filled in, rules were created for the proper management of the FMEA process at a company. Experimental verification of implementing the FMEA principles at a company confirmed the topicality of the problems solved, and the importance of using one of the quality tools in the production process of the company.

\section{References}

[1] BUCKO, M. (2017). Application of a Procedural FMEA for the Production of Bearings: Master Thesis. Ostrava: VŠB - Technical University of Ostrava. Faculty of Mechanical Engineering. Department of Mechanical Technology, 2017, 69 p. Thesis head: Schindlerová, V.

[2] PANTAZOpOUlos, G., TSinOpoulos, G. (2005). Process Failure Modes and Effects Analysis (PFMEA): A Structured Approach for Quality Improvement. In: The Metal Forming Industry, Vol. 5, 2005, pp. 5 - 10. ISSN 15477029. DOI: $10.1361 / 15477020522933$.

[3] KREJCI, L., SCHINDLEROVA, V., BUCKO, M., HLAVATY, I. (2018). Application of a Process FMEA for the Welding. In: Metal 2018. Conference proceedings: reviewed version: 27 th International Conference on Metallurgy and Materials: May 23rd-25th 2018. Ostrava: Tanger, 2018, pp. 1145-1150. ISBN 978-808729484-0.

[4] LIJESH, K., P., MUZAKKIR, S., M., HIRANI, H. (2016). Failure Mode and Effect Analysis of Passive Magnetic Bering. In: Engineering Failure Analysis, Vol. 62, 2016, pp. 1 - 20. ISSN 13506307.

[5] REHMAN, Z., KIFOR, V., C. (2016). An Ontology to Support Semantic Management of FMEA Knowledge. In: International Journal of Computers Communications \& Control, Vol. 11, 2016, pp. 507 - 521. ISSN 1841-9836.

[6] KONAR, R., MICIAN, M., HLAVATY, I. Defect Detection in Pipelines During Operation Using Magnetic Flux Leakage and Phased Array Ultrasonic Method. In: Manufacturing Technology, Vol. 14, 2014. ISSN 1213-2489.
[7] HLAVATY, I., KOZAK, J., KREJCI, L. (2016). Study of the Weld Deposit Properties Contained Tungsten Carbides in the Iron Matrix. In: Metal 2016. Brno: 2016, pp. 1056 - 1060. ISBN 97880-87294-67-3.

[8] PIATKOWSKI, J., KAMINSKI, P. (2017). Risk Assessment of Defect Occurrences in Engine Piston Castings by FMEA Method. Foundry Commission of the Polish Academy of Sciences. Vol. 17, 2017, pp. 107 - 110. ISBN 2299-2944

[9] LEHOCKA, D., HLAVATY, I., HLOCH, S. (2016). Rationalization of Material Flow in Production of Semitrailer Frame for Automotive Industry. In: Tehnicki Vjesnik-Technical Gazette, Vol. 23, 2016, No. 4, pp. 1215 - 1220. ISSN 13303651 (Print), ISSN 1848-6339 (Online).

[10] HLAVATY, I., KOZAK, J., KREJCI, L., SAMARDZIC, I., TUOMINEN, J. (2017). The Effect of Tungsten Carbide Particles Content in a Weld Deposit on its Abrasion Resistance. In: Tehnicki Vjesnik-Technical Gazette, Vol. 24, 2017, No. 5, pp. 1345 - 1349. ISSN 1330-3651 (Print), ISSN 1848-6339 (Online).

[11] ALDRIDGE, J., R., TAYLOR, J., DALE, B., G. (1991). The Application of Failure Mode and Effects Analysis of an Automotive Components Manufacturer, In: International Journal Quality Reliability Management, Vol. 8, 1991, pp. 44 - 56. ISSN 0265-671X.

[12] BAGHERY, M., YOUSEFI, S., REZAEE, J., M. (2016). Risk Measurement and Prioritization of Auto Parts Manufacturing Processes Based on Process Failure Analysis, Interval Data Envelopment Analysis and Grey Relational Analysis. In: Springer Science+Business Media New York 2016. DOI 10.1007/s 10845-016-1214-1.

[13] SCHINDLEROVA, V., SAJDLEROVA, I. (2017). Influence Tool Wear in Material Flow. In: Advances in Science and Technology-research Journal, 2017, year 11, issue 1, pp. $161-165$.

[14] FRIES, J., HAPLA, T. (2018). Influence Affecting the Lifetime of Belt Conveyor's Drive Drums. In: Tehnicki Vjesnik, Osijek. Vol. 25, 2018, pp. 7 - 14. ISSN 1330 3651. WOS: 000433290300002.

[15] HRUBY, J., SCHINDLEROVA, V., RENTKA, J. (2015). Degradation Processes in the Contact Layers of Forming Tools. In: Manufacturing Technology, Vol. 15, 2015, No. 5, pp. 836 - 842. ISSN 1213-2489.

[16] BOHACIK, M., MICIAN, M., KONAR, R., HLAVATY, I. (2017). Ultrasonic Testing of Butt Weld Joint by TOFD Technique. In: Manufacturing Technology, Vol. 17, 2017, No. 6, pp. $842-$ 847. ISSN 1213-2489. 